短 報

\title{
肥育豚の盲腸内容物と回結腸リンパ節からの サルモネラの分離
}

\author{
佐藤 博 $^{\dagger}$ 齊藤こずえ 原 智之阿部久司 \\ 新潟県長岡食肉衛生検査センター（９ 940-2464＼cjkstart長岡市新開町 2956-11）
}

(2020 年 2 月 3 日受付 $\cdot 2020$ 年 8 月 13 日受理)

要約

われわれは, 肥育豚の盲腸内容物と回結腸リンパ節からサルモネラを分離し, 豚のサルモネラ保菌検查における回結 腸リンパ節の有用性及び回結腸リンパ節の増菌培養時間について検討した。 25 農場中 3 農場（12\%）, 250 頭中 13 頭 （5.2\%）がサルモネラ陽性であった。 その後の陽性 2 農場の継続調査を含め, 340 頭中 52 頭（15\%）からサルモネラ が分離された．盲腸内容物のサルモネラ陽性率は $10 \%(34 / 340)$, 回結腸リンパ節のそれは $11 \%(38 / 340)$ であり, 統計的に有意差はなかった。しかし, 盲腸内容物のみの結果では供試豚のサルモネラ保菌率は $10 \%$ となるが, 回結腸 リンパ節の結果を合わせると保菌率は $15 \%$ に上昇した。したがって，盲腸内容物のみでなく回結腸リンパ節も材料と して用いることにより, 豚のサルモネラ保菌状況をより正確に把握できると考えられる. また, 回結腸リンパ節の増菌

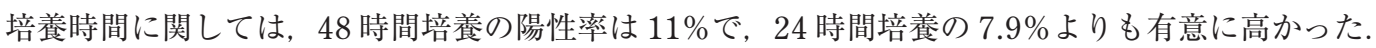

——ーワード : 盲腸内容物, 回結腸リンパ節, サルモネラ.

日獣会誌 $74 ， 255 \sim 258(2021)$

サルモネラ食中毒は世界的に重要な細菌性食中毒の一 つであり，主要な原因食品は鶏卵をはじめとした畜産物 とされている [1]．畜産物のサルモネラ污染は家畜がサ ルモネラを保菌することに起因している，家畜の腸管等 に保菌されるサルモネラや体表に付着したサルモネラ は, と畜場や食鳥処理場での解体工程においてと体を污 染することがあり，これが食肉のサルモネラ污染につな がっている [2]。また，家禽に関しては，卵形成・産卵 過程における卵のサルモネラ污染が知られている $[3]$.

サルモネラ食中毒との関係から，国内外で家畜のサル モネラ保菌状況が調査されており，豚に関しても多数の 報告がある. 豚の保菌調査の材料として, 国内では一般 に糞便や盲腸内容物が用いられている [4-6]. 一方, 海外では腸管関連リンパ節，すなわち空腸リンパ節（腸 間膜リンパ節と同義）や回結腸リンパ節も用いられてい る [7-10]. Katsube ら [11] は, 腸内容物の中では盲 腸内容物が，腸管関連リンパ節の中では回腸のリンパ節 がサルモネラの陽性率が高いと報告している。 そこで, 豚のサルモネラ保菌調査における腸管関連リンパ節の有
用性を検討するために，盲腸内容物と回結腸リンパ節か らサルモネラを分離し, 結果を比較した。 また, リンパ 節からのサルモネラ分離に関し，増菌培養時間について も検討した.

\section{材 料 及び方 法}

2018 年 10 月～ 2019 年 9 月に, 所管と畜場に搬入さ れた新潟県内 25 農場の 34 ロット, 340 頭の外見上健康 な肥育豚から次の 2 調査区分でサルモネラを分離した。

農場調査 : サルモネラ污染のある農場を把握するため に, 25 農場の各 10 頭, 合計 250 頭から盲腸内容物と回 結腸リンパ節を採取した。盲腸内容物は消毒したメスで 盲腸を切開後, 滅菌綿棒で $0.1 \sim 0.5 \mathrm{~g}$ を採取し, 回結 腸リンパ節は消毒した検査刀で切り取り採取した。いず れの材料も検查用ターンテーブル上で，他の個体からの 污染を避けて採取した。盲腸内容物を綿棒ごと $10 \mathrm{~m} l$ の ラパポート・バシリアディス培地（日水製薬(株，東京）

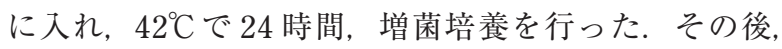
MLCB 培地（日水製薬(株), 東京）と $1 \mathrm{mg} / \mathrm{m} l$ のスルファ

$\dagger$ 連絡責任者：佐藤 博（新潟県長岡食肉衛生検査センター）

于 940-2464 長岡市新開町 2956-11 『 0258-27-6508 FAX 0258-27-9313

E-mail : sato.hiroshi5@pref.niigata.lg.jp 
肥育豚の盲腸内容物と回結腸リンパ節からのサルモネラの分離

表 1 調査区分別のサルモネラ分離状況

\begin{tabular}{|c|c|c|c|c|}
\hline 区 分 & 農場・ロット & 検査頭数 & 陽性頭数 & 検查年 /月 \\
\hline \multirow{4}{*}{ 農場調査 } & A 農場 & 10 & 1 & $2018 / 11$ \\
\hline & B 農場 & 10 & 4 & $2019 / 1$ \\
\hline & $\mathrm{C}$ 農場 & 10 & 8 & $2018 / 11$ \\
\hline & その他 22 農場* & 220 & & \\
\hline \multirow{9}{*}{ 継続調査 } & A 農場· 1 & 10 & 6 & $2019 / 4$ \\
\hline & $\mathrm{A}$ 農場・2 & 10 & & $2019 / 4$ \\
\hline & $\mathrm{A}$ 農場· 3 & 10 & 7 & $2019 / 5$ \\
\hline & $\mathrm{A}$ 農場· 4 & 10 & & $2019 / 7$ \\
\hline & $\mathrm{A}$ 農場 $\cdot 5$ & 10 & 7 & $2019 / 9$ \\
\hline & $\mathrm{B}$ 農場· 1 & 10 & 7 & $2019 / 3$ \\
\hline & $\mathrm{B}$ 農場・2 & 10 & 2 & $2019 / 6$ \\
\hline & B 農場·3 & 10 & 4 & $2019 / 6$ \\
\hline & B 農場· 4 & 10 & 6 & $2019 / 7$ \\
\hline 計 & & 340 & 52 & \\
\hline
\end{tabular}

*サルモネラ陰性農場を一括.

検査期間は 2018 年 10 月 2019 年 3 月.

ピリジン（富士フイルム和光純薬(株)，東京）を添加した ブリリアントグリーン培地（栄研化学(株), 東京）に $10 \mu \mathrm{l}$ のループで塗抹し, $37^{\circ} \mathrm{C} て ゙ 24$ 時間, 分離培養を行った. 両培地に発育したサルモネラを疑うコロニーをそれぞれ 3 個まで釣菌し, TSI 培地（栄研化学(株)，東京）と LIM 培地（日水製薬(株），東京）でスクリーニング後，市販免 疫血清（サルモネラ免疫血清「生研」, デンカ生研(株), 新潟）で型別した，回結腸リンパ節については, 消毒し たハサミで周囲の脂肪組織を除去し，表面をガスバー ナーの炎で焼洛後, 滅菌ハサミで細切し, $2 \mathrm{~g}$ をサンフ リングバックに入れた。これに $20 \mathrm{~m} l$ の細菌培養液 (Nutrient Broth No.2, OXOID, U.K.) を加えて 1 分間 ストマック後, $37^{\circ} \mathrm{C}$ で 24 時間, 48 時間, 増菌培養し, それぞれの時点で盲腸内容物と同様に分離, 同定を行っ た。 なお，盲腸内容物の増菌培養では，田口ら [12］の 方法を参考に試料を直接ラパポート・バジリアディス培 地に接種した。また, 回結腸リンパ節の増菌培養では, 試料中に競合菌は存在しない, または少ないと考え, 非 選択性増菌培地でもサルモネラの増殖は妨害されないと 推定し, 上記培養液を用いた.

継続調査：保菌調査でサルモネラ污染が確認された A 農場と B 農場について, 農場調査と同様にサルモネラ の分離を継続した. 搬入日の異なる豚群を 1 ロットとし, A 農場については 5 ロット 50 頭, B 農場については 4 ロット 40 頭の合計 90 頭を検査した。

統計処理法：盲腸内容物と回結腸リンパ節のサルモネ ラ陽性率の差, また回結腸リンパ節の 24 時間増菌培養 と 48 時間増菌培養での陽性率の差については, マクネ マー検定を実施した.
表 2 材料別のサルモネラ分離頭数

\begin{tabular}{cccrr}
\hline \hline & & \multicolumn{2}{l}{ 回結腸リンパ節 } & \multirow{2}{*}{ 計 } \\
\cline { 3 - 4 } & & + & - & \\
\hline 盲腸内容物 & + & 20 & 14 & 34 \\
\hline 計 & - & 18 & 288 & 306 \\
\hline
\end{tabular}

表 3 増菌培養時間別の回結腸リンパ節からのサルモネラ 分離頭数

\begin{tabular}{ccccc}
\hline \hline & & \multicolumn{2}{c}{48 時間 } & \multirow{2}{*}{ 計 } \\
\cline { 3 - 4 } & & + & - & \\
\hline \multirow{2}{*}{24 時間 } & + & 27 & & 27 \\
& - & 11 & 302 & 313 \\
\hline 計 & & 38 & 302 & 340 \\
\hline
\end{tabular}

\section{成}

\section{績}

農場調査：25農場中 3 農場 $(12 \%), 250$ 頭中 13 頭 (5.2\%) がサルモネラ陽性であった。農場により 1 〜 8 頭の保菌豚が検出された（表 1 ）。陽性農場の A 農場と B 農場については継続調査を実施した。

継続調査：A農場では 5 ロット中の 3 ロット（60\%） がサルモネラ陽性で, 50 頭中の 20 頭 (40\%) からサル モネラが分離された。 また， B 農場では 4 ロット中の 4 ロット (100\%) がサルモネラ陽性で, 40 頭中の 19 頭 （48\%）からサルモネラが分離された（表 1). なお，A 農場については初回調查の 2018 年 11 月から最終調査 の 2019 年 9 月まで, 11 カ月にわたり断続的にサルモネ ラが分離された。また, B 農場については初回調査の 2019 年 1 月から最終調査の 2019 年 7 月まで, 7 カ月に わたり連続してサルモネラが分離された（表 1$)$.

材料別の分離状況：調査全体を通して, 盲腸内容物で は 340 頭中の 34 頭（10\%）から, 回結腸リンパ節では 340 頭中の 38 頭（11\%）からサルモネラが分離された (表 2). 盲腸内容物と回結腸リンパ節の両方ともサルモ ネラ陽性が 20 頭 $(5.9 \%)$, 盲腸内容物のみ陽性が 14 頭 (4.1\%), 回結腸リンパ節のみ陽性が 18 頭 (5.3\%) あり, 合計で 52 頭 (15\%) の保菌豚が検出された（表 2)。な お, 盲腸内容物と回結腸リンパ節のサルモネラ陽性率に は，マクネマー検定で有意差はなかった $(P>0.05)$ 。こ れに関して，農場により傾向が異なる可能性があるの で, 供試豚の多い A 及び B 農場について個別に検定し たが，いずれにおいても有意差はなかった.

増菌培養時間別の分離状況：回結腸リンパ節 340 検 体中, 24 時間増菌培養では 27 検体 $(7.9 \%)$ から, 48 時間増菌培養では 38 検体（11\%）からサルモネラが分 
表 4 農場別のサルモネラ血清型

\begin{tabular}{lcccc}
\hline \hline \multicolumn{1}{c}{ 血清型 } & A 農場 & B 農場 & C 農場 & 計 \\
\hline$S$. Rissen & 10 & 16 & & 26 \\
$S$. (4:i:-) & 9 & 7 & & 16 \\
$S$. Braenderup & 5 & & 6 & 11 \\
$S$. Altona & & & 2 & 2 \\
\hline \multicolumn{1}{c}{ 計 } & 24 & 23 & 8 & 55 \\
\hline
\end{tabular}

離された（表 3). 24 時間増菌培養と 48 時間増菌培養 の両方ともサルモネラ陽性が 27 検体 $(7.9 \%), 48$ 時間 増菌培養のみ陽性が 11 検体（3.2\%） あり，合計で 38 検体（11\%）からサルモネラが分離された（表 3). 24 時間増菌培養と 48 時間増菌培養のサルモネラ陽性率に は，マクネマー検定で有意差があった $(P<0.01)$.

血清型：調査全体で, 3 農場の 52 頭から 55 株, 4 種 のサルモネラ血清型が分離され，A農場ではSalmonella Rissen (S. Rissen) と S. (4:i:-) が主で, B農場で は $S$. Rissen が, C 農場では $S$. Braenderup が優勢で あった（表 4)。なお，盲腸内容物と回結腸リンパ節で 異なる血清型が分離された例があり，A農場の 1 ロット の 3 頭において，それぞれ $S$. Rissen と $S$. Braenderup が分離された。

\section{考察}

農場調査において，養豚場の $12 \%$, 肥育豚の $5.2 \%$ か らサルモネラが分離された。国内の豚のサルモネラ保菌 率について，吉田ら［4］は 1970 年代後半の $23.1 \%$, 1980 年代後半の $5.7 \%$ を報告し, 保菌率の低下を指摘し ている. Futagawa-Saito ら [5] は 1998〜 1999 年の $2.2 \% ， 2004 ２ 005$ 年の $3.3 \%$ を，木嶋ら［6］は 2003 〜 2005 年の $3.1 \%$ を報告している. また，農林水産省 の「食品安全に関する有害微生物の実態調査の結果集」 では，2010～2013 年の保菌率を年により 0～4\%と公表 している (https://www.maff.go.jp/j/syouan/seisaku/ kekka/chikusan.html)。これらの報告及び本調査結果 から, 豚のサルモネラ保菌率は 1980 年代後半から低下 したことがうかがえるが, 現在でも豚の数\%が保菌して いると推定される。したがって，サルモネラは依然とし て豚肉の危害要因であることに変わりはない。また，A 農場では 11 力月， B 農場では 7 力月にわたりサルモネ ラが分離されたことから, サルモネラが農場にいったん 侵入すると，長期間生残すると考えられる。

保菌豚の中には，盲腸内容物のみサルモネラ陽性の個 体と回結腸リンパ節のみ陽性の個体があったことから, いずれか一方の検査では保菌率が過小評価される可能性 がある，具体的には，盲腸内容物のみの結果では供試豚 のサルモネラ保菌率は $10 \%$ であるが，回結腸リンパ節 の結果を合わせると保菌率は $15 \%$ に上昇した。したがっ
て，盲腸内容物と回結腸リンパ節の両方を検査すること により，保菌状況をより正確に把握できると考えられ る. 本調査では, 盲腸内容物と回結腸リンパ節のサルモ ネラ陽性率に有意差はなかった。 Bahnsonら [7], Mainar-Jaime ら［8］は盲腸内容物の方が陽性率は高 いと報告しているが, Tayら [9], Dorrら [10］は逆 に腸間膜リンパ節の方が陽性率は高いと報告しており, 傾向は一定しない. これは, 盲腸内容物や糞便からのサ ルモネラ分離が試料の接種量や使用培地等の検査方法の ほか, 競合菌, 間欠的な排菌や菌数など, さまざまな影 響を受けやすいためと推定される。一方，腸管関連リン パ節について, 欧州食品安全機関では糞便に比ベリンパ 節は競合菌のレベルが低く, サルモネラ菌数が小さくて も容易に分離されると評価している（https://efsa. onlinelibrary.wiley.com/doi/epdf/10.2903/j. efsa.2006.341)。本調査では, 回結腸リンパ節からのサ ルモネラ分離に非選択性増菌培地を用いたが, その陽性 率は盲腸内容物と同等であった。これは, 欧州食品安全 機関の評価を支持する結果と思われ，リンパ節はサルモ ネラ保菌調査の材料として有用と考えられる.

回結腸リンパ節からのサルモネラ分離では, 陽性率は 48 時間増菌培養の方が 24 時間増菌培養よりも有意に高 かった。これは増菌培養時間を 48 時間に延長したこと により, サルモネラ菌数の低い検体でも十分に増菌させ ることができ，検出可能になったためと推定された。 ま た, 回結腸リンパ節と盲腸内容物で異なる血清型が分離 された例があったが，この理由として血清型による組織 侵入性の違いや感染時期のずれなどが, 可能性として考 えられた。

今回分離されたサルモネラは，S. Rissen, S. (4:i:-), S. Braenderup がほとんどを占めた. S. Braenderup は前述の報告 [4] にあるが，S. Rissen 及び $S$. (4:i:-) は みられない [4-6]. 動物医薬品検査所の「薬剂耐性菌の モニタリング」(https://www.maff.go.jp/nval/yakuzai/ yaku-zai_p3.html）では，2000 年からの成績が公表さ れているが, 両血清型は豚由来株として 2012 年の調査 から登場する. よって, $S$. Rissen 及び $S$. (4:i:-) は比 較的新しく流行した血清型と思われ，新潟県内において もこれらの血清型の流行がうかがえる. 一方, 人由来の サルモネラ血清型については, 国立感染症研究所の「病 原微生物検出情報」の 2016 年統計（https://www.niid. go.jp/niid/images/iasr/archive/2016/bac/salm16. pdf）によると, S. Saintpaul, S. Thompson, S. Eiteritidis などが上位を占めるが，ほかにも多様な血清型が 分離されている。 その中で $S$. (4:i:-) は上位 10 に入っ ており，S. Braenderup, S. Rissenも少ないが分離例 があり，これらの血清型は豚と人で共通している.

サルモネラは依然として豚肉の危害要因であること, 
豚に流行する血清型は変わることから，定期的な保菌調 査が必要である。その材料として, 盲腸内容物及び腸管 関連リンパ節を用いること，そしてリンパ節については 48 時間増菌培養を行うことが推奨される。

\section{引用 文 献}

[1] 田口真澄, 泉谷秀昌 : サルモネラ, 食品衛生検查指針 微 生物編 2015, 269-283, 日本食品衛生協会, 東京 (2015)

[2] 仲西寿男：サルモネラ症の疫学, 食衛誌, 35, 585-592 (1994)

[3] Gantois I, Ducatelle R, Pasmans F, Haesebrouck F, Gast R, Humphrey TJ, Van Immerseel F : Mechanisms of egg contamination by Salmonella Enteritidis, FEMS Microbiol Rev, 33, 718-738 (2009)

［4］吉田孝治, 高橋 勇, 澤田拓士：1975～1989 年に食肉 衛生検查所へ搬入された健康豚のサルモネラ保菌状況と その血清型，日本細菌学雑誌，50，537-545（1995）

[5] Futagawa-Saito K, Hiratsuka S, Kamibeppu M, Hirosawa T, Oyabu K, Fukuyasu T : Salmonella in healthy pigs: prevalence, serotype diversity and antimicrobial resistance observed during 1998-1999 and 2004-2005 in Japan, Epidemiol Infect, 136, 1118-1123 (2008)
［6］木嶋眞人, 山本孝史：養豚場に扔けるサルモネラ污染状 況，豚病会報，51，1-4（2007）

[7] Bahnson PB, Fedorka-Cray PJ, Ladely SR, MateusPinilla NE : Herd-level risk factors for Salmonella enterica subsp. enterica in U.S. market pigs, Prev Vet Med, 76, 249-262 (2006), (online), (https://doi. org/10.1016/j.prevetmed.2006.05.009), (accessed 2020-1-15)

[8] Mainar-Jaime RC, Atashparvar N, Chirino-Trejo M, Rahn K : Survey on Salmonella prevalence in slaughter pigs from Saskatchewan, Can Vet J, 49, 793-796 (2008)

[9] Tay SCK, Robinson RA, Pullen MM : Salmonella in the mesenteric lymph nodes and cecal contents of slaughtered sows, J Food Protect, 52, 202-203 (1989)

[10] Dorr PM, Tadesse DA, Zewde BM, Fry P, Thakur S, Gebreyes WA : Longitudinal study of Salmonella dispersion and the role of environmental contamination in commercial swine production systems, Appl Environ Microb, 75, 1478-1486 (2009)

[11] Katsube Y, Tanaka Y, Imaizumi K, Masuda K : Salmonella carriers in swine, Jpn J Vet Sci, 35, 25-31 (1973)

[12］田口真澄, 泉谷秀昌 : Salmonella, 食品由来感染症と食 品微生物, 154-191, 中央法規出版, 東京 (2009)

\section{Isolation of Salmonella from Cecal Content and Ileocolic Lymph Nodes of Finishing Pigs \\ Hiroshi $\mathrm{SATO}^{\dagger}$, Kozue SAITO, Tomoyuki HARA and Hisashi ABE \\ * Niigata Prefectural Nagaoka Meat Inspection Center, 2956-11 Shinkaimachi, Nagaoka, 940- 2464, Japan}

\section{SUMMARY}

We isolated Salmonella from cecal content and ileocolic lymph nodes of finishing pigs, and examined the usefulness of ileocolic lymph nodes. We also examined the enrichment culture time of the ileocolic lymph nodes. Three of 25 farms (12\%), and 13 of 250 (5.2\%) pigs harbored Salmonella. Then, we examined Salmonella isolation in pig carried by positive 2 farms. In total, we found 52 of 340 (15\%) pigs possessed Salmonella. The Salmonella-positive rate of the cecal content was $10 \%$, which was not statistically different from $11 \%$ of ileocolic lymph nodes. However, the results of only the cecal content showed that the Salmonella carriage rate of the test pigs was $10 \%$, but the carriage rate increased to $15 \%$ when the results of the ileocolic lymph nodes were combined. Therefore, it is considered that the use of ileocolic lymph nodes as well as cecal content as materials can provide a more accurate picture of Salmonella carriage in pigs. As for the enrichment culture time of the ileocolic lymph nodes, the positive rate of the 48 -hour culture was $11 \%$, significantly higher than $7.9 \%$ of 24-hour culture. — Key words : cecal content, ileocolic lymph nodes, Salmonella.

$\dagger$ Correspondence to : Hiroshi SATO (Niigata Prefectural Nagaoka Meat Inspection Center)

2956-11 Shinkaimachi, Nagaoka, 940-2464, Japan

TEL 0258-27-6508 FAX 0258-27-9313 E-mail : sato.hiroshi5@pref.niigata.lg.jp 